12. Brookshire BL, Fletcher JM, Bohan TP Landry SH, Davidson KC, Francis DJ. Verbal and nonverbal skill discrepancies in children with hydrocephalus: A Five-Year Longitudinal Follow-Up. J Pediat Psycol 1995; 20: 785-800.

13. Fletcher JM, Bohan TP, Brandt ME, Kramer LA, Brookshire BL, Thorstad K, Davidson KC, Francis DJ, McCauley SR, Baumgartner JE. Morphometric evaluation of the hydrocephalic brain: Relationships with cognitive development. Child's Nerv Syst 1996; 12: 192-9.

14. Brodal A. Anatomia neurológica com correlações clínicas. $3^{\mathrm{a}}$ ed. São Paulo, ROCA, 1984: 338 e 679-84.

15. Wright LC, MCallister II JP, Katz SD, Miller DW, Lovely TJ, Salotto AG, Wolfson BJ . Cytological and cytoarchitectural changes in the feline cerebral cortex during experimental infantile hydrocephalus. Pediatr Neurosurg 1990; 91: 139-155.

16. McLone DG. Consensus: modelling of hydrocephalus. Child's Nerv Syst 1994; 10: 24-8.
17. Donders J, Canady AI, Rourke BP Psychometric intelligence after infantile hydrocephalus. A critical review and reinterpretation. Child's Nerv Syst 1990; 6: 148-54.

18. Hirsch J-F. Consensus: long-term outcome in hydrocephalus. Child's Nerv Syst 1994; 10: 64-9.

19. Hochwald GM. Animal models of hydrocephalus: recent developments. Proc Soc Exp Biol Med 1985; 178: 1-11.

20. Hasan D, Tanghe HLJ. Distribution of cisternal blood in patients with acute hydrocephalus after subarachnoid hemorrhage. Ann Neurol 1992; 31: 374-8.

21. Matsumoto T, Nagai H, Fukushima T, Mase M. Analysis of intracranial pressure pulse wave in experimental hydrocephalus. Child's Nerv Syst 1994; 10; 91-5.

22. Chumas PD, Drake JM, Del Bigio MR, Silva M, Tuor UI. Anaerobic glycolysis preceding white-matter destruction in experimental neonatal hydrocephalus. J Neurosurg 1994; 80: 491-501.

23. Da Silva MC, Drake JM, Lemaire C, Cross A, Tuor UI. High-energy phosphate metabolism in a neonatal model of hydrocephalus before and after shunting. J Neurosurg 1994; 81: 544-53.

24. Del Bigio MR, Kanfer JN, Zhang YW. Myelination delay in the cerebral white matter of immature rats with kaolin-induced hydrocephalus is reversible. J Neuropathol Exp Neurol 1997; 56: 1053-66.

25. Tashiro Y, Drake JM. Reversibility of funtionally injured neurotransmitter systems with shunt placement in hydrocephalus rats: implications for intellectual impairment in hydrocephalus. J Neurosurg 1998; 88: 709-17.

26. Elberger AJ. The functional role of the corpus callosum in the developing visual system: a review. Prog Neurobiol 1982; 18: 15-79.

27. Massicotte EM, Buist R, Del Bigio MR. Altered diffusion and perfusion in hydrocephalic rat brain: a magnetic resonance imaging analysis. J Neurosurg 2000; 92: 442-7.

28. Shapiro K, Takei F, Fried A, Kohn I. Experimental feline hydrocephalus. The role of biomechanical changes in ventricular enlargement in cats. J Neurosurg 1985; 63: 82-7.

Lopes LS, Machado HR, Lachat J-J. Estudo do corpo caloso de ratos Wistar submetidos à hidrocefalia experimental. Acta Cir Bras [serial online] 2003 vol 18 suppl 5. Disponível em www.scielo.br/acb

RESUMO- Objetivo: A hidrocefalia causa inúmeros danos cerebrais, especialmente nas estruturas ao redor dos ventrículos cerebrais. As crianças com hidrocefalia apresentam déficits nas aquisições não verbais mais do que nas verbais, nem sempre revertidos com o tratamento precoce. Como o corpo caloso tem um papel essencial nas aquisições não verbais, é provável que as lesões nesta estrutura estejam envolvidas com as disfunções cognitivas dessas crianças. Este trabalho procura estabelecer as alterações causadas pela hidrocefalia, induzida pela injeção de caulim intracisternal ao corpo caloso de ratos Wistar em desenvolvimento. Métodos: Sete, 14 e 21 dias após a injeção, os animais foram sacrificados, sendo o corpo caloso dissecado e processado para estudo das fibras axonais. Resultados e Conclusões: Os ratos com 7 dias de evolução da hidrocefalia apresentaram um atraso na mielinização em relação aos controles. Em ratos com 14 dias de evolução da hidrocefalia, o corpo caloso mostrou recuperação da mielina, mas em ratos com hidrocefalia com 21 dias de evolução, as fibras apresentavam-se lesadas e reduzidas em número.

DESCRITORES: Corpo caloso. Hidrocefalia. Mielina. Rato Wistar.

Correspondence to:

Luiza da Silva Lopes

Faculdade de Medicina de Ribeirão Preto/USP

Departamento de Cirurgia e Anatomia

Setor de Anatomia

Av. Bandeirantes, 3900

14049-900 Ribeirão Preto, São Paulo, Brasil

e-mail: luslopes@fmrp.usp.br

Conflict of interest: none

Financial support: FAEPA

6-ARTIGO ORIGINAL

\title{
Brachial plexus variations in its formation and main branches
}

Valéria Paula Sassoli Fazan ${ }^{1,}$ André de Souza Amadeu², Adilson L. Caleffi ${ }^{2,}$ Omar Andrade Rodrigues Filho ${ }^{3}$

Fazan VPS, Amadeu AS, Caleffi AL, Rodrigues Filho OA. Brachial plexus variations in its formation and main branches. Acta Cir Bras [serial on line] 2003 vol 18 suppl 5. Available in www.scielo.br/acb.

ABSTRACT - Purpose: The brachial plexus has a complex anatomical structure since its origin in the neck throughout its course in the axillary region. It also has close relationship to important anatomic structures what makes it an easy target of a sort of variations and provides its clinical and surgical importance. The aims of the present study were to describe the brachial plexus anatomical 
variations in origin and respective branches, and to correlate these variations with sex, color of the subjects and side of the body. Methods: Twenty-seven adult cadavers separated into sex and color had their brachial plexuses evaluated on the right and left sides. Results: Our results are extensive and describe a large number of variations, including some that have not been reported in the literature. Our results showed that the phrenic nerve had a complete origin from the plexus in $20 \%$ of the cases. In this way, a lesion of the brachial plexus roots could result in diaphragm palsy. It is not usual that the long thoracic nerve pierces the scalenus medius muscle but it occurred in $63 \%$ of our cases. Another observation was that the posterior cord was formed by the posterior divisions of the superior and middle trunks in $9 \%$. In these cases, the axillary and the radial nerves may not receive fibers from $\mathrm{C} 7$ and $\mathrm{C} 8$, as usually described. Conclusion: Finally, the plexuses studied did not show that sex, color or side of the body had much if any influence upon the presence of variations.

KEY WORDS: Anatomy. Axilla. Brachial plexus. Anatomical variations. Peripheral nerves.

\section{INTRODUCTION}

The nerve supply of the upper limb arises from the eleventh cranial nerve, the cervical plexus and through the brachial plexus. At the brachial plexus, nerve fibers are routed from different levels of the spinal cord to enter one of the terminal nerves that supply the upper limb. It must be remembered that the brachial plexus is merely a routing mechanism to get nerves with a common function into the proper terminal nerves and thus errors in distribution may occur that are corrected distally in the arm, forearm or hand, resulting in anatomical variations of the plexus ${ }^{1}$. Some variations are vulnerable to damage in radical neck dissection and other surgical operations of the axilla and upper $\mathrm{arm}^{2}$. Also, a very close course of an unusual brachial plexus branch with the axillary artery may lessen the blood supply of the upper extremity by compressing the vessel ${ }^{3}$. Moreover, it seems that certain surgical treatment failures of brachial plexus lesions are related to the presence of anatomical variations. Due to the surgical importance of the brachial plexus, the aims of the present study were to describe its anatomical variations in origin and respective branches, and to correlate these variations with sex, color of the subjects and side of the body.

\section{METHODS}

A total of 27 embalmed human cadavers of both sexes ( 21 males and 6 females) and two distinct colors (12 white and 15 black), in a total of 54 upper extremities were studied (27 from each side). The age of death ranged from 37 to 76 years and all specimens were fixed in $10 \%$ formaldehyde solution. The upper limbs have been partially dissected by the School of Medicine of Triângulo Mineiro medical students during the previous years and, the authors did further dissections under magnification, with the aid of a D.F. Vasconcellos M-90 surgical microscope. A classic brachial plexus was defined when the superior trunk was formed by the union of $\mathrm{C} 5$ and $\mathrm{C} 6$ roots, the middle trunk was the continuation of $\mathrm{C} 7$ root and the inferior trunk was formed by the union of $\mathrm{C} 8$ and $\mathrm{T} 1 \operatorname{roots}^{4,5}$. The terminal branches of the brachial plexus were considered as being the axillary, radial, ulnar, median and musculocutaneous nerves. From the supraclavicular part, the origins of the dorsal scapular, long thoracic, suprascapular, subescapular, thoracodorsal, medial pectoral and lateral pectoral nerves were studied. Also, the origins of the phrenic and accessory phrenic nerves were evaluated. From the infraclavicular part, the origins of the medial brachial cutaneous and the medial antebrachial cutaneous nerves were studied. Variations of the trunks, divisions and cords were also explored, as well as the origin of the terminal branches. The obtained results are of a descriptive order and data are presented as absolute numbers and percentage of the total.

\section{RESULTS}

From the 54 upper extremities evaluated, 39 (72\%) showed normal origin of the brachial plexus. Thirteen plexuses (24\%) were prefixed in origin, 2 from male and 11 from female, being 5 in white and 8 in black cadavers $(54 \%$ on the right and $46 \%$ on the left side). Only 3 plexuses were postfixed in origin, being all from male white cadavers, 2 on the right and 1 on the left side. Eleven phrenic nerves $(20 \%)$ originated entirely from the brachial plexus in 9 male and 2 female, being 6 white and 5 black cadavers $(73 \%$ on the right and $27 \%$ on the left sides). An accessory phrenic nerve was present on 12 plexuses, $50 \%$ on each side, in 9 male and 3 female, being 5 in white and 7 in black cadavers. When the nerves arising from the roots of the brachial plexus were evaluated (54 in total), only 45 plexuses presented the dorsal scapular branch, $12(27 \%)$ of which were completely out of the middle scalene muscle during their course (Figure 1).

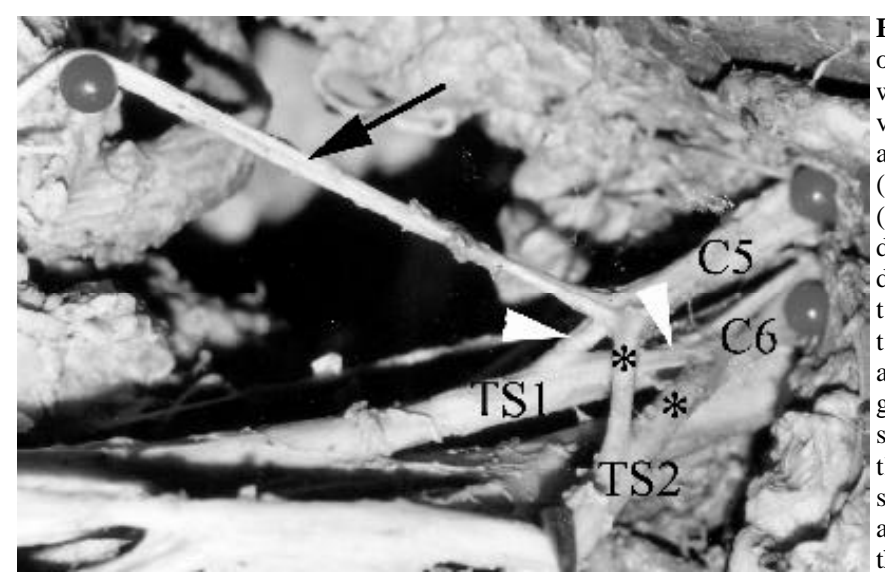

FIGURE 1 - Anterior view of a right brachial plexus with a superior trunk variation. $\mathrm{C} 5$ and $\mathrm{C} 6$ roots are split in anterior (asterisks) and posterior (white arrowheads) divisions. Both posterior divisions join to give origin to a "posterior superior trunk" (TS1) and both anterior divisions join to give origin to an "anterior superior trunk" (TS2). Note the presence of a dorsal scapular branch (black arrow) completely out of the scalenus medius muscle.

Thirty-three $(73 \%)$ dorsal scapular nerves had an intramuscular course in 26 male and 7 female, being 15 in white and 18 in black cadavers. The long thoracic nerve was formed by $\mathrm{C} 5$ and $\mathrm{C} 6$ in $33 \%$ (17 plexuses), by C5, C6 and C7 in $46 \%$ (24 plexuses) and by C6 and C7 in $15 \%$ ( 8 plexuses) of the cases. No female cadavers presented a long thoracic nerve formed as the last description. The long thoracic nerve pierced the middle scalene muscle in $63 \%$ of the cases. Variation on the superior trunk was present in 2 plexuses, both on the right side. In both cases, C5 and C6 roots were split in anterior and posterior division (Figure 1). Both anterior divisions joined to give origin to an "anterior superior trunk" and both posterior divisions joined to give origin to a "posterior superior trunk". These trunks joined to give origin to the superior trunk.

The middle trunk received a communicating branch from $\mathrm{C} 8$ on the left side in one male white cadaver and a communicating branch from the inferior trunk on the right side in one male black cadaver. The inferior trunk was not variable in our cases.

1. Assistant Professor, Departament of Surgery and Anatomy, School of Medicine of Ribeirão Preto, University of São Paulo, Ribeirão Preto, São Paulo, Brazil.

2. Medical Student, School of Medicine of Triângulo Mineiro, Uberaba, Minas Gerais; Brazil.

3. Graduate Student and Instructor in Anatomy, School of Medicine of Triângulo Mineiro, Uberaba, Minas Gerais; Brazil. 
The posterior cord was formed by the posterior divisions of the superior and middle trunks on 5 plexuses (9\%), all from male black cadavers (Figure 2). The lateral and medial cords were not variable in our cases.

Table 1 shows the variations in origin of the latera pectoral, medial pectoral, suprascapular and thoracodorsal nerves. Table 2 shows the variations in origin of the upper subscapular, lower subscapular, medial brachial cutaneous and medial antebrachial cutaneous nerves. Also, a medial cutaneous trunk, which gave origin to the medial antebrachial cutaneous and medial brachial cutaneous nerves, was present in 36 plexuses
(67\%), 29 in male and 19 in black cadavers. From these, 2 medial cutaneous trunks, both on the right side from male black cadavers, originated from the inferior trunk of the brachial plexus.

From the terminal branches of the brachia plexus, the axillary and the musculocutaneous nerves were not variable in origin. In 4 male cadavers ( 2 white and 2 black, 1 one the right and 3 on the left side), the musculocutaneous nerve, after piercing the coracobrachialis muscle, gave off a communicating branch to the median nerve, which was normal in its origin (Figure 3 ). The radial nerve received a communicating branch from the inferior trunk in 4 cases $(7 \%)$, all in male black cadavers, 3 on the right and 1 on the left side. The ulnar nerve received a communicating branch from the lateral cord in 16 cases $(30 \%)$, being 12 male and 4 female cadavers (Figure 4). The median nerve was formed by 2 lateral roots and 1 medial root (from the medial cord) in $28(52 \%)$ cases, being 25 from male and 3 from female, 9 from white and 19 from black cadavers. In 4 cases, one of the two lateral roots came from the anterior division of the middle trunk and 1 from the lateral cord. On the other 24 cases, the two lateral roots came from the lateral cord of the plexus. Four (7\%) median nerves were formed distally, in the arm (Figure 3).

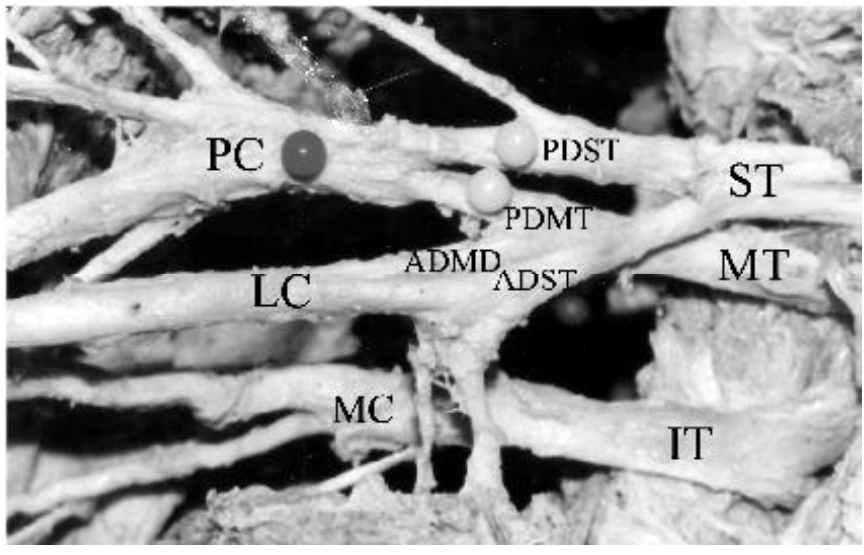

FIGURE 2 - Anterior view of a right brachial plexus with the posterior cord (PC) formed only by the posterior divisions of the superior (PDST) and middle $(\mathrm{PDMT})$ trunks. $\mathrm{ST}=$ superior trunk, $\mathrm{MT}=$ middle trunk, $\mathrm{IT}$ $=$ inferior trunk, $\mathrm{ADMD}=$ anterior division of the middle trunk, ADST = anterior division of the superior trunk, $\mathrm{LC}=$ lateral cord, $\mathrm{MC}=$ medial cord.

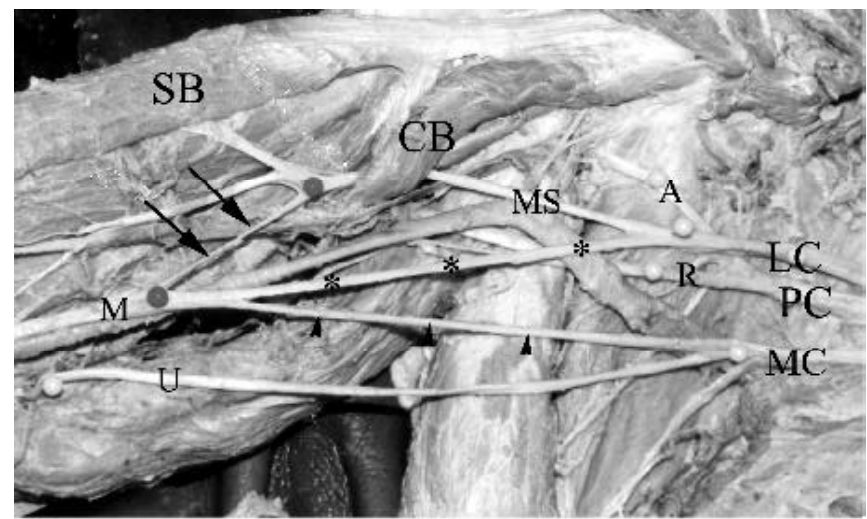

FIGURE 3 - Anterior view of a right brachial plexus showing a communicating branch (black arrows) between the musculocutaneous nerve (MS) and the median nerve (M), after piercing the coracobrachialis muscle $(\mathrm{CB}) . \mathrm{LC}=$ lateral cord, $\mathrm{PC}=$ posterior cord, $\mathrm{MC}=$ medial cord, $\mathrm{A}=$ axillary nerve, $\mathrm{R}=$ radial nerve, $\mathrm{U}=$ ulnar nerve. Asterisks indicate the lateral root of the median nerve and black arrowheads indicate the medial root of the median nerve. $\mathrm{SB}=$ short head of the biceps brachii muscle. Note that the median nerve is formed distally in the arm.

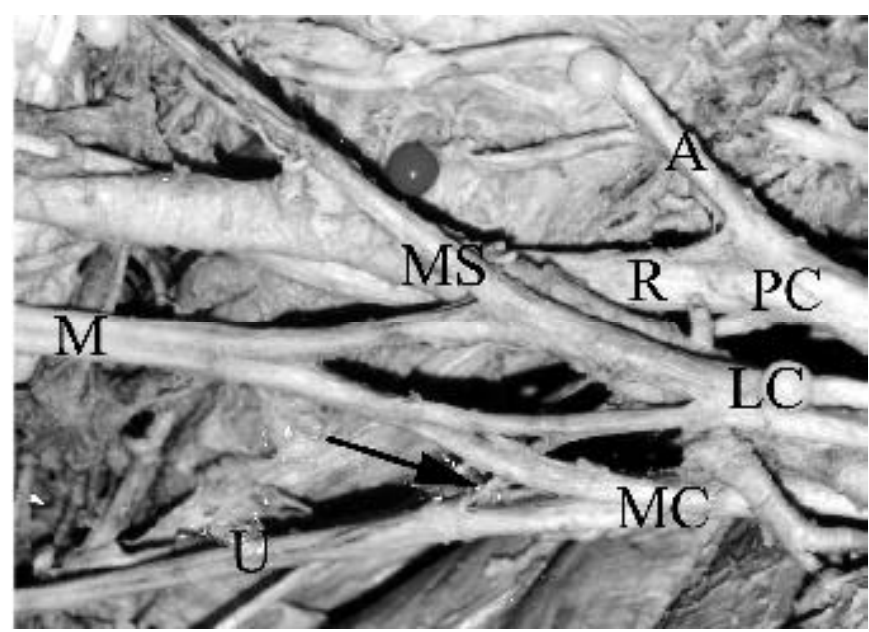

FIGURE 4 - Anterior view of a right brachial plexus showing a communicating branch (black arrow) between the lateral cord (LC) and the ulnar nerve $(\mathrm{U}) . \mathrm{PC}=$ posterior cord, $\mathrm{MC}=$ medial cord, $\mathrm{A}=$ axillary nerve, $\mathrm{R}=$ radial nerve, $\mathrm{MS}=$ musculocutaneous nerve, $\mathrm{M}=$ median nerve. 
TABLE 1 - Variations in origin of the lateral pectoral, medial pectoral, suprascapular and thoracodorsal nerves. Normal origins were considered as the lateral cord for the lateral pectoral nerve, the medial cord for the medial pectoral nerve, the superior trunk for the suprascapular nerve and the posterior cord for the thoracodorsal nerve.

\begin{tabular}{|c|c|c|c|c|c|c|c|c|}
\hline Nerve & Abormal Origin & Total Number & Male (42) & Female (12) & $\begin{array}{c}\text { White } \\
\text { (12) }\end{array}$ & Black $(30)$ & Right (27) & Left (27) \\
\hline \multirow[t]{2}{*}{ Lateral Pectoral } & $\begin{array}{l}\text { Anterior Division of } \\
\text { the Superior Trunk }\end{array}$ & $24(44 \%)$ & $19(45 \%)$ & $5(42 \%)$ & $9(75 \%)$ & $15(50 \%)$ & $9(33 \%)$ & $15(55 \%)$ \\
\hline & Middle Trunk & $3(5.5 \%)$ & $2(4.8 \%)$ & $1(8.3 \%)$ & - & $3(10 \%)$ & $3(11 \%)$ & - \\
\hline Medial Pectoral & $\begin{array}{l}\text { Anterior Division } \\
\text { of the Middle Trunk }\end{array}$ & $5(9 \%)$ & $4(9.5 \%)$ & $1(8.3 \%)$ & - & $5(17 \%)$ & $1(3.7 \%)$ & $4(15 \%)$ \\
\hline Suprascapular & $\mathrm{C} 5$ & $3(5.5 \%)$ & $1(2.4 \%)$ & $2(17 \%)$ & - & $3(10 \%)$ & $1(3.7 \%)$ & $2(7.4 \%)$ \\
\hline \multirow[t]{2}{*}{ Thoracodorsal } & Axillaris nerve & $7(13 \%)$ & $6(14 \%)$ & $1(8.3 \%)$ & $3(25 \%)$ & $4(13 \%)$ & $2(7.4 \%)$ & $5(18 \%)$ \\
\hline & Radial nerve & $3(5.5 \%)$ & $3(7.1 \%)$ & $3(25 \%)$ & $3(25 \%)$ & - & $1(3.7 \%)$ & $2(7.4 \%)$ \\
\hline
\end{tabular}

TABLE 2 - Variations in origin of the superior subscapular, inferior subscapular, medial antebrachial cutaneous and medial brachial cutaneous nerves. Normal origins were considered as the posterior cord for the superior and inferior subscapular nerves and the medial cord for the medial brachial and medial antebrachial cutaneous nerves.

\begin{tabular}{|c|c|c|c|c|c|c|c|c|}
\hline Nerve & Abnormal Origin & $\begin{array}{c}\text { Total Number } \\
(54)\end{array}$ & Male (42) & Female (12) & $\begin{array}{c}\text { White } \\
(24)\end{array}$ & Black (30) & Right (27) & Left (27) \\
\hline \multirow[t]{2}{*}{ Upper Subscapular } & $\begin{array}{l}\text { Posterior Division } \\
\text { of the Superior Trunk }\end{array}$ & $32(59 \%)$ & $23(55 \%)$ & $9(75 \%)$ & $14(58 \%)$ & $18(60 \%)$ & $14(58 \%)$ & $\begin{array}{c}18 \\
(67 \%)\end{array}$ \\
\hline & Axillaris nerve & $3(5.5 \%)$ & $2(4.8 \%)$ & $1(8.3 \%)$ & $2(8.3 \%)$ & $1(3.3 \%)$ & $2(7.4 \%)$ & $1(3.7)$ \\
\hline Lower Subscapular & Axillaris nerve & $29(54 \%)$ & $23(55 \%)$ & $6(50 \%)$ & $13(54 \%)$ & $16(53 \%)$ & $13(48 \%)$ & 16 \\
\hline $\begin{array}{l}\text { Medial Brachial } \\
\text { Cutaneous nerve }\end{array}$ & Inferior Trunk & $5(9 \%)$ & $4(9.5 \%)$ & $1(8.3 \%)$ & $3(12 \%)$ & $2(6.7 \%)$ & $3(11 \%)$ & $2(7.4 \%)$ \\
\hline $\begin{array}{l}\text { Medial } \\
\text { Antebrachial } \\
\text { Cutaneous Nerve }\end{array}$ & Inferior Trunk & $1(2 \%)$ & $1(2.3 \%)$ & - & $1(4.2 \%)$ & - & - & $1(3.7 \%)$ \\
\hline
\end{tabular}

\section{DISCUSSION}

Knowledge of variations in anatomy is important to anatomists, radiologists, anesthesiologists and surgeons, and has gained more importance due to the wide use and reliance on computer imaging in diagnostic medicine ${ }^{5}$. Also, the presence of anatomic variations of the peripheral nervous system is often used to explain unexpected clinical signs and symptoms. Descriptions of nerve variations are useful in clinical/surgical practice since an anatomical variation can be the cause of a nerve palsy syndrome due to a different relation of a nerve and a related muscle. In most of these cases, surgery can lead to a rapid recovery of nerve function ${ }^{6}$. Although a brachial plexus injury during neck surgery is a rare condition, especially due to its protection by a dense layer of deep cervical fascia surrounding the scalenus muscles and also the protection of its roots between the scalenus anterior and scalenus medius muscle, anatomical variations of the brachial plexus may render it vulnerable to injury during routine surgical neck dissection ${ }^{7}$. In our observations, the dorsal scapular branch was completely out of the scalenus medius muscle during its course in $27 \%$, being vulnerable to injury in neck surgical procedures. Also, because of the relatively large number of prefixed plexuses ( $24 \%$ in our cases), the phrenic nerve originated entirely from the plexus in $20 \%$ of the cases. An injury to the plexus in the neck, in these cases, could result in unexplained diaphragm palsy.

$\mathrm{Kerr}^{8}$ extensively revised the anatomy of the brachial plexus in man and, classified this anatomical structure into 3 groups and 7 subgroups. Although most of the variations reported in that study were also present in ours, with some differences in the percentages (probably due to the large number of cases studied in that study), some variations remained to be described. In our observations, we found a middle trunk which received a communicating branch from $\mathrm{C} 8$ what could be an indicative that the musculocutaneous nerve may receive fibers also from $\mathrm{C} 8$, what has not been previously reported. Another observation from our material is that the posterior cord from 5 plexuses was formed by the posterior divisions of the superior and middle trunks. This observation is suggestive that, in some cases, the axillary and the radial nerves may not receive fibers from $\mathrm{C} 7$ and $\mathrm{C} 8$, as usually described. The origin of the suprascapular nerve from C5 is mentioned by Tountas and Bergman ${ }^{1}$ and was present in $5.5 \%$ of our cases. The origin of the upper subscapular nerve from the axillary nerve and the origin of the lower subscapular nerve from the thoracodorsal nerve were also not described before.

The presence of communicating branches between the terminal branches of the brachial plexus was relatively common in our material. The existence of communicating branches may be of importance in the evaluation of unexplained sensory loss after trauma or surgical intervention in a particular area ${ }^{9}$.

The absence of the musculocutaneous nerve was described by LeMinor ${ }^{10}$ and by Nakatani and Tanaka $^{11,12}$ and in all these cases, the lateral cord pierced the coracobrachialis muscle and inervated the anterior muscles of the arm. In our series, none of the brachial plexuses presented such variation. The formation of the median nerve by three roots was described by Sargon et al. ${ }^{3}$ on a male cadaver. In this case, the authors reported the presence of two roots coming from the lateral cord, one of them with a very close course over the axillary artery. The same variation was present in $52 \%$ of our material and one must be 
aware that this kind of variation is more prone to injury in surgical operations of the axilla and that, the very close course of the second lateral root of the median nerve to the axillary artery may lessen the blood supply of the upper extremity by compressing the vessel ${ }^{3}$.

Although some differences were present in our material, a pattern of variations for sex, color or side of the body was not evident. As also described by $\mathrm{Kerr}^{8}$, the plexuses studied did not show that sex, color or side of the body had much if any influence upon the presence of variations.

\section{REFERENCES}

1. Tountas CP, Bergman RA. Anatomic Variations of the Upper Extremity. Churchill Livingstone, New York, 1993.

2. Uzun A, Seeling LL Jr. A Variation in the Formation of the Median Nerve:
Communicating Branch Between the Musculocutaneous and Median Nerves in Man. Folia Morphol 2002; 60: 99-101.

3. Sargon MF, Uslu SS, Celik HH, AkÄit D. A Variation of the Median Nerve at the Level of the Brachial Plexus. Bull Assoc Anat 1995; 79: 25-6.

4. Agur AMR. Grant's Atlas of Anatomy. $9^{\text {th }}$ Ed. Baltimore: Williams \& Wilkins, 1991.

5. Harry WG, Bennett JDC, Guha SC. Scalene Muscles and the Brachial Plexus: Anatomical Variations and Their Clinical Significance. Clin Anat 1997; 10: 250-2.

6. Megele R. Anterior Interosseus Nerve Syndrome with Atypical Nerve Course in Relation to the Pronator Teres. Acta Neurochir 1988; 91: 144-6.

7. Gacek RR. Neck Dissection Injury of a Brachial Plexus Anatomical Variant. Arch Otolaryngol Head Neck Surg 1990; 116: 356-8.
8. Kerr AT. The Brachial Plexus of Nerves in Man, the Variations in its Formation and Branches. Am J Anat 1918; 23: 285-395.

9. Hoogbergen MM, Kauer JM. An Unusual Ulnar Nerve-Median Nerve Communicating Branch. J Anat 1992; 181: 513-6.

10. LeMinor JM. A Rare Variation of the Median Nerve and Musculocutaneous Nerve in Man. Arch Anat Histol Embryol 1990; 73: 33 42 .

11. Nakatani T, Tanaka S. Absence of the Musculocutaneous Nerve with Innervation of Coracobrachialis, Biceps Brachii, Brachialis and the Lateral Border of the Forearm by Branches from the Lateral Cord of the Brachial Plexus. J Anat 1997; 191: 459-60.

12. Nakatani T, Tanaka S. Two Rare Anomalies of the Brachial Plexus. J Anat 1998; 192: 303-4.

Fazan VPS, Amadeu AS, Caleffi AL, Rodrigues Filho OA. Brachial plexus variations in its formation and main branches. Acta Cir Bras [serial on line] 2003 vol 18 suppl 5. Disponível em www.scielo.br/acb.

RESUMO - Objetivos: O plexo braquial apresenta uma estrutura anatômica complexa, desde sua origem, no pescoço, até sua ramificação terminal, na região axilar. Ele também apresenta relações importantes com outras estruturas anatômicas locais, o que o torna vulnerável ao aparecimento de uma série de variações anatômicas, marcando sua importância clínica e cirúrgica. Os objetivos desse estudo foram de descrever as variações anatômicas do plexo braquial, desde sua origem até seus ramos terminais e correlacionar essas variações com o sexo e a cor dos indivíduos, bem como com o lado do corpo estudado. Métodos: Vinte e sete cadáveres adultos, separados em sexo e cor, tiveram seus plexos braquiais avaliados à direita e à esquerda. Resultados: Nossos resultados são extensos e descrevem um grande número de variações, incluindo algumas ainda não descritas na literatura. Nossos resultados mostram que o nervo frênico apresentou sua origem diretamente no plexo braquial em $20 \%$ dos casos. Assim, uma lesão das raízes do plexo braquial poderia resultar em uma inexplicada paralisia diafragmática. Não é esperado que o nervo torácico longo passe através do músculo escaleno médio entretanto, esse fato foi observado em $63 \%$ de nossos casos. Outra observaçõa foi a formação do fascículo posterior pelas divisões posteriores dos troncos superior e médio em $9 \%$ dos casos. Nesses casos, os nervos axilar e radial poderão não receber fibras de C7 e C8, como normalmente descrito na literatura. Conclusão: Os plexos braquiais estudados não mostraram que o sexo, a cor ou o lado do corpo influenciam de maneira importante na presença de variações anatômicas dessa estrutura.

DESCRITORES: Anatomia. Axila. Plexo braquial. Variações anatômicas. Nervos periféricos.

Correspondence to:

Valéria Paula Sassoli Fazan, M.D.; Ph.D.

Department of Surgery and Anatomy

School of Medicine of Ribeirão Preto - University of São Paulo

Av. Bandeirantes 3900, Ribeirão Preto - SP

14049-900 - Brazil

Phone: + 5516 602-2407

FAX: + 5516 633-0017

e-mail: vpsfazan@fmrp.usp.br

Conflict of interest: None

Financial Support: FAPEMIG grant $n^{\circ}$ CBS 8011896, CNPq grant $n^{\circ} 501230 / 2003-3$ and FAPESP grant $n^{\circ} 02 / 09406-5$.

7-ARTIGOORIGINAL

\title{
Pancreatic capillary blood flow during caerulein-induced pancreatitis evaluated by a laser-doppler flowmeter in rats
}

\author{
Roberto Ferreira Meirelles Jr. ${ }^{1}$, Reginaldo Ceneviva ${ }^{2}$, José Liberato Ferreira Caboclo ${ }^{3}$, Michael M. Eisenberg ${ }^{4}$
}

Meirelles RF Jr, Ceneviva R, Caboclo JLF, Eisenberg MM. Pancreatic capillary blood flow during caerulein-induced pancreatitis evaluated by a laser-doppler flowmeter in rats. Acta Cir Bras [serial online] 2003 vol 18 suppl 5. Available in www. Scielo.br/acb.

ABSTRACT - Purpose: The pancreatic capillary blood flow (PCBF) was studied to determine its alterations during caerulein-induced pancreatitis in rats. Methods: Twenty rats were divided in groups: control and caerulein. A laser-Doppler flowmeter to measure PCBF continuously was used. Blood pressure (BP) and heart rate (HR) were monitored. Serum biochemistry analyses were determined. 